\title{
Quality of Annual Reporting: The Empirical Evidence from Banks in Cambodia
}

\author{
Soth Sreymoch ${ }^{1}$, Kong Yusheng ${ }^{2}$ \\ ${ }^{1}$ Jiangsu University, School of Finance and Economics, No. 301 Xuefu Road, Zhenjiang, Jiangsu, P.R.China \\ ${ }^{2}$ Dean of School of Finance and Economics, Jiangsu University, China, No. 301 Xuefu Road, Zhenjiang, Jiangsu, P.R.China
}

\begin{abstract}
This paper aims to evaluate the quality of the annual reporting of fifty bank institutions in Cambodia. High quality of financial reporting is the sole method for the stakeholders such as managers, employees, customers, and especially governments, creditors, and investors to understand about financial position of a company. Base on the qualitative characteristics of IFRS, financial reporting's quality contains Fundamental concepts (relevance and faithful presentation) and Enhancing concepts (comparability, verifiability, timeliness, and understandability). The study used annual reports of fifty banks in Cambodia published in 2016. Using a five-point Likert type scale on 33 questions and 100 participants, the result has shown that the annual reports needs more improvement especially on quality of consistency. Among the seven qualitative characteristics of annual reporting, consistency of annual reports of bank in Cambodia receives less rating scale, 1.99. However, none of the other qualities reach 3.00 rating scale, which indicate that the annual reports need more improvement in all concepts. The annual reports should present the information in a faithful manner, increase relevance information and timely issue the annual reports.
\end{abstract}

Keywords: Annual Reports, Banks, Quality Characteristic, Stakeholders

\section{Introduction}

In response to highly demand from stakeholders such as managers, employees, customers, and especially governments, creditors, and investors; financial reporting has undergone various remodeling to pledge interested parties for their serenity and conviction. High quality of financial reports shrinks the gap of asymmetry information of the corporation's current execution between internal and external stakeholders. Generally, outer shareholders do not have the access or privilege to make decision about the entity's internal control, so financial report is sole mean presenting useful material which they acquire for decision making on investment, creditworthiness, and federal tax collection. Normally, financial report contains accounting policies, financial statements, chairman's letter, auditor's report and the company's business vision for the future (Pivac, Vuko, \& Cular, 2017). Quality of financial reporting falls into many perspectives. Based on, IFRS's (International Financial Reporting Standard) Conceptual Framework, qualitative characteristic of financial reporting contains Fundamental concepts (relevance and faithful presentation) and Enhancing concepts (comparability, verifiability, timeliness, and understandability) ("International Financial Reporting Standard," 2010). However, there is no exact mechanism stated precisely of how to measure those aspects. Consequently, many corporate accounting scandals have arisen and caused huge impact on world economy and market efficiency, for instance, Enron, WorldCom, and Global Crossing in the United States, Daewoo Group in Korea, Parmalat in Italy, and $\mathrm{HIH}$ in Australia (Eun \& Resnick, 2012).

Many researches have been conducted in related topic associating financial reporting quality. However, most of them were focused on developed and western countries, but lesser were concentrated in developing and eastern countries.
Cambodia is one of the minority which has never been investigated regarding the above field. Being acknowledge of this incompetence, this paper will be the primary research which shall encourage more researchers to shift the direction of concentration to developing and eastern nations. Cambodia is one of the fastest growing economy in Southeast Asia with average growth rate 7.6\% in 1994-2015 ("The World Bank in Cambodia," 2017). Cambodian Accounting Standard (CAS) is fully adopted all International Financial Reporting Standards (IFRSs) and is compelled by all business entities in Cambodia (Finance, 2017). Bank sector in Cambodia is also keep on growing and nowadays it consists of 50 Commercial and Specialized Banks. This paper aims to evaluate the quality of the financial reporting of these fifty banks in Cambodia, specifically in 2016. In addition, it is hoped to contribute rising the awareness of the significance of financial reporting and enhance the financial reporting quality in Cambodia.

\section{Literature Review}

The objective of financial reporting is to provide essential financial information to the interested party such as potential equity investors, lenders and other creditors in making decisions in their capacity as capital providers (Whittington, 2008). However, the crucial point is how financial reporting quality can be measured. Based on qualitative characteristics of financial reporting by FASB and IASB (2008), Ferdy, Geert and Suzanne constructed a compound measurement tool to comprehensively assess the quality of financial reporting using 231 annual reports from companies listed at US, UK, and Dutch stock markets in 2005 and 2007 (Beest, Braam, \& Boelens, 2009). Similarly, Nguyen Thanh Cuong and Do Thi Ly used qualitative characteristic to measure and assess the quality of information on the annual reports of seafood's listed companies on Vietnam Stock Market (Cuong \& Thi Ly, 2017). Applying the same treatment on

\section{Volume 8 Issue 4, April 2019 www.ijsr.net}




\section{International Journal of Science and Research (IJSR) \\ ISSN: 2319-7064}

ResearchGate Impact Factor (2018): 0.28 | SJIF (2018): 7.426

Bangladesh financial report, Hasan, Adullah and Hossain found that external users (shareholders, stockbrokers, bankers, academicians and tax officers) had negative attitude towards the disclosures far below the standard qualitative characteristics, so they suggested that Board of Directors (BOD) should improve reporting quality by presenting more sincerity and integrity (Hasan, Abdullah, \& Hossain, 2014).

In spite of focusing on qualitative characteristics of financial reporting directly, many researchers believed that there were other tools to access its quality such as earnings management, financial restatements, and timeliness (Barth, Landsman, Lang, Stanford, \& Graduate School of, 2007; Cohen, Krishnamoorthy, \& Wright, 2004; Schipper \& Vincent, 2003). Transparency of financial reporting requirement reduces earnings management in the area of increase transparency or change the focus of earnings management to less visible method (Hunton, Libby, \& Mazza, 2006). Moreover, audit committees are responsible for evaluating financial reporting quality, so they are likely to change the structure and focus of audit committee discussions about financial reporting quality, and may affect the committee's overall assessment of the quality of a company's financial reports (McDaniel, Martin, \& Maines, 2002). Besides, the effectiveness of control exercised over executive remuneration weakens corporate governance which results in better disclosure information (Forker, 1992). Independent auditors also play an important role as gatekeepers serving the public interest and protecting investors by providing them with relevant, reliable, and understandable financial information (Bailey \& Gramling; Nicolaisen, 2004). An extend research about the quality of financial reporting in term of national-level by Qingliang, Huifa and Zhijun underlined Financial Reporting Quality Index (FRQI). Aside from IFRS and GAAP (Generally Accepted Accounting Principles) which have been used as a proxy to evaluate the quality of financial report, it was claimed to be insufficient. Financial reporting quality may differ due to complex interactions among many factors, making it inherently difficult to measure, especially across borders (Qingliang, Huifa, \& Zhijun, 2016). Snjezana Pivac, Tina Vuko, and Marko Cular analyzed the quality of annual report disclosures of companies selected in European transition countries (Croatia, Montenegro, Romania, Serbia and Slovenia) and compared their disclosure quality; they found that regardless of the fact that in the area of financial reporting and auditing all companies have adopted appropriate accounting acts and standards, differences can be found in the overall business environment, as well as in the difference in EU membership status and socio-political characteristics (Pivac et al., 2017).

In conclusion, depending on diverse perspectives, various authors evaluated the quality of financial reporting using qualitative characteristics, which have been issued by FASB and IASB, which can be addressed as direct approach; on the other hand other researchers tested the quality by analyzing surrounding subjects such as earnings management, financial restatements, timeliness, corporate governance, independent auditors, FRQI, DQI and separate legal tender; which can be remarked as indirect approach.

\section{Literature Review on Methodologies Assessing Quality of Financial Reporting}

Many researches have been operationalized to access the quality of information in annual reporting, including direct and indirect methods. Focusing on specific elements of qualitative characteristics of financial reporting, Ferdy, Geert, and Suzanne created compound measurement tool to comprehensively assess the quality of financial reporting. They produced five-point rating scales to assess the scores on 21 items which operationalized the fundamental and enhancing qualitative characteristics (Beest et al., 2009). Adopting the same method, Nguyen Thanh Cuong and Do Thi Ly conducted a research on annual reports of 20 seafood listed companies in two Vietnam stock exchange market (HOSE and HNX) in 2013 (Cuong \& Thi Ly, 2017). The data was collected using two means, interviews and surveys of target groups: (1) expert groups; (2) evaluate the group's annual report; (3) group is evaluated using the annual reports of the object (Cuong \& Thi Ly, 2017). Emphasizing on external target users' (shareholders, stockbrokers, bankers, academicians and tax officers) perspective, Hasan et al. studied qualitative characteristics of financial reporting in Bangladesh using questionnaire and five-point Likert type scale (Hasan et al., 2014).

Based on prior research which revealed that transparency of financial reporting could detect earnings management, Hunton et al. constructed similar hypothesis experimenting on 62 financial executives and chief executive officers by allowing them decide which available-for-sale security to sell from a portfolio and found that more transparent reporting requirement would reduce earnings management (Hunton et al., 2006). Independent auditor is important for watching over the financial reporting to ensure that it is truthful. Andrew et al. discussed about this matter and contended four determinants of Financial Reporting Quality focusing on the independent audit: (1) the reports prepared by management, (2) internal audit activity, (3) oversight by the audit committee, and (4) the audit performed by the independent auditor (Bailey \& Gramling). 


\section{International Journal of Science and Research (IJSR) \\ ISSN: 2319-7064}

ResearchGate Impact Factor (2018): 0.28 | SJIF (2018): 7.426

Qingliang et al. developed Financial Reporting Quality Index (FRQI) by using a sample of 38 main world capital markets which contained 700 total firm years from 2000 to 2014; It captured six dimensions of accounting and auditing quality: the loss avoidance ratio (LAR), profit decline avoidance ratio (PDAR), accruals ratio (AR), qualified audit opinion ratio (QAOR), non-big four auditor ratio (NBAR), and audit fee ratio (AFR) (Qingliang et al., 2016). In order to access the quality of disclosure, Pivac et al. used disclosure quality index for annual reports (DQI) which was constructed in five stages: (1) evaluating the significance of annual report (AR) elements; (2) calculating the importance coefficient of AR elements (C.I.j); (3) calculating the assessment quality of the AR (A.Q.j); (4) calculating the overall quality of the AR; and (5) creating the disclosure quality index for annual reports (DQI). The survey was conducted in 2012 on 40 accounting and financial experts and scientists from Croatian universities, and the respondents were evaluating particular aspects using 1-5 Likert scale (Pivac et al., 2017).

\section{Methodology Development}

This research is intended to measure the quality of annual reporting by adopting the qualitative characteristics of IFRS: relevance, faithful presentation, comparability, verifiability, timeliness, and understandability. Following the method in prior papers, well-designed questionnaire and a five-point Likert type scale will be applied to collect data with a sample size of 100 participants, whose background are scholars, professors or experts, who have great knowledge and experience in related field; and it will be tested on financial reports of fifty banks (36 Commercial Banks and 14 Specialized Banks) in 2016.

\subsection{Relevance $(\mathbf{R})$}

According to Conceptual Framework of Financial Reporting, the relevance of information refers to the capability of making a difference in decision making by virtue of its predictive or confirmatory value (Dear, 2008). Predictive value contains in financial reporting helps users to forecast ultimate outcome of past, present and future events. A Financial report has confirmatory value or feedback value when it provides confirmation on the previous predictive value whether it is true or not. Appropriate measure for Relevance (R): R1; R2; R3; R4; R5; R6; R7; R8; R9; R10; $\mathrm{R} 11 ; \mathrm{R} 12 ;$ \& R13.

\subsection{Faithful Presentation (F)}

The other quality of fundamental qualitative characteristics is faithful presentation. To fulfill this requirement, financial reports must encompass three qualifications: completeness, freedom from material error, and neutrality (Dear, 2008). Financial report which is complete should include all necessary information which is required by users. Plus, financial report should be ensured its accuracy and free from any errors or uncertainty. Last but not least, neutrality refers to information which is free from bias, for instance, manipulating result or performance of the entity to create a better image. Appropriate measure for Faithful Presentation (F): F1; F2; F3; F4; \& F5.

\subsection{Verifiability $(\mathrm{V})$}

Verifiability refers to the ability of producing similar results, regardless of different methods employed or independent measurers. According to conceptual framework verifiability "is a quality of information that helps assure users that information faithfully represents the economic phenomena that it purports to represent", and may be direct (an amount or other representation itself is verified) or indirect (the amount or other representation is verified by checking the inputs and recalculating the outputs using the same accounting convention or methodology) (Dear, 2008). Verifiability sometimes cannot be completely separate from Faithful Presentation. These two qualities co-exist to form other quality call Reliability. Appropriate measure for Verifiability (V): V1; V2; V3; \&V4.

\subsection{Comparability (C)}

Comparability allows users to analyze information about the business with other businesses to find their analogy and diversification of economic phenomena. Comparability is the goal; consistency is a means and refers to the use of the same accounting policies and procedures, either from period to period within an entity or in a single period across entities (Dear, 2008). Appropriate measure for Comparability (C): $\mathrm{C} 1 ; \mathrm{C} 2 ; \mathrm{C} 3 ; \mathrm{C} 4 ; \mathrm{C} 5$; \& C6.

\subsection{Understandability (U)}

Understandability is one of the quality in Enhancing Concept of Conceptual Framework. It refers to the ability to comprehend meaning of economic information presented in financial report. Understandability is enhanced when information is classified, characterized and presented clearly and concisely (Dear, 2008). Users are supposed to have sufficient knowledge of business to be able to read financial report. Appropriate measure for Understandability (U): U1; U2; U3; U4; U5; \& U6.

\subsection{Timeliness $(\mathrm{T})$}

Timeliness indicates attainment of financial report being issued in a timely manner. If users cannot obtain all relevant information on time that it is needed or until it loses value, they may lose the chance of investment and make wrong decisions. Some information may continue to be timely long after the end of a reporting period because some users may continue to consider it when making decisions (Dear, 2008). Appropriate measure for Timeliness (T): T1

Table 1: Summary of literature review and methodology adoption

\begin{tabular}{|c|c|c|c|c|}
\hline Research Topic & Methodology & Results & Authors & Year \\
\hline $\begin{array}{c}\text { Quality of Financial Reporting: } \\
\text { measuring qualitative characteristics }\end{array}$ & Qualitative Characteristics & $\begin{array}{c}\text { The measurement used in this study } \\
\text { is a valid and reliable approach. }\end{array}$ & $\begin{array}{c}\text { Ferdy van Beest, Geert } \\
\text { Braam and Suzanne }\end{array}$ & \begin{tabular}{c} 
2009 \\
\hline
\end{tabular}
\end{tabular}

\section{Volume 8 Issue 4, April 2019 www.ijsr.net}


International Journal of Science and Research (IJSR)

ISSN: 2319-7064

ResearchGate Impact Factor (2018): 0.28 | SJIF (2018): 7.426

\begin{tabular}{|c|c|c|c|c|}
\hline & & & Boelens & \\
\hline $\begin{array}{l}\text { Measuring and Assessing the Quality } \\
\text { of Information on the Annual Report: } \\
\text { The Case of Seafood's Companies } \\
\text { Listed on the Vietnam Stock Market }\end{array}$ & \begin{tabular}{|l|} 
Qualitative Characteristics \\
\end{tabular} & $\begin{array}{c}\text { The quality of information must first } \\
\text { appropriate and honest. }\end{array}$ & $\begin{array}{c}\text { Nguyen Thanh Cuong, and } \\
\text { Do Thi Ly }\end{array}$ & 2017 \\
\hline $\begin{array}{l}\text { Qualitative Characteristics of } \\
\text { Financial Reporting }\end{array}$ & Qualitative Characteristics & $\begin{array}{l}\text { The information should be more } \\
\text { sincerity and integrity. }\end{array}$ & $\begin{array}{c}\text { Shamimul Hasan, Shamsul } \\
\text { Nahar Bin Abdullah, and } \\
\text { Syed Zabid Hossain }\end{array}$ & 2014 \\
\hline $\begin{array}{l}\text { Financial Reporting Transparency } \\
\text { and Earnings Management }\end{array}$ & $\begin{array}{l}\text { Experiment on available- } \\
\text { for-sale security }\end{array}$ & \begin{tabular}{|c|} 
More transparent reporting \\
requirement would reduce earnings \\
management.
\end{tabular} & $\begin{array}{l}\text { James E. Hunton, Robert } \\
\text { Libby, and Cheri L. Mazza }\end{array}$ & 2006 \\
\hline $\begin{array}{c}\text { Financial Reporting Quality: A Focus } \\
\text { on the Role of the Independent } \\
\text { Auditor }\end{array}$ & $\begin{array}{c}\text { Determinants of Financial } \\
\text { Reporting Quality: A } \\
\text { Focus on the Independent } \\
\text { Audit } \\
\end{array}$ & $\begin{array}{c}\text { Independent auditors play an } \\
\text { important role as gatekeepers serving } \\
\text { the public interest and protecting } \\
\text { investors. }\end{array}$ & $\begin{array}{c}\text { Andrew D. Bailey, Jr. and } \\
\text { Audrey A. Gramling } \\
\end{array}$ & 2015 \\
\hline \begin{tabular}{c|} 
How to Measure Country-Level \\
Financial Reporting Quality?
\end{tabular} & \begin{tabular}{c|}
$\begin{array}{c}\text { Financial Reporting } \\
\text { Quality Index }\end{array}$ \\
\end{tabular} & $\begin{array}{c}\text { FRQI is appropriate for country- } \\
\text { level studies. }\end{array}$ & $\begin{array}{c}\text { Qingliang Tang, Huifa Chen } \\
\text { and Zhijun Lin } \\
\end{array}$ & 2016 \\
\hline $\begin{array}{c}\text { Analysis of Annual Report } \\
\text { Disclosure Quality for Listed } \\
\text { Companies in Transition Countries }\end{array}$ & $\begin{array}{l}\text { Disclosure quality index } \\
\text { (DQI) }\end{array}$ & $\begin{array}{l}\text { According to DQI, the most } \\
\text { successful and transparent } \\
\text { companies are in Slovenia }\end{array}$ & $\begin{array}{c}\text { Snjezana Pivac, Tina Vuko, } \\
\text { and Marko Cular }\end{array}$ & 2017 \\
\hline
\end{tabular}

\section{Data Collection}

Base on the data of annual reports from National Bank of Cambodia, we extracted the information specifically on 2016. The questionnaire was sent attaching with annual reports of banks by email or other social media method to participants. In some cases, direct interview might be required depend on the availability of the participants. Using questionnaire is a convenience way for collecting data, save time and comfortable for the participates. We have 50 annual reports and 100 participates, which means two people would evaluate on the same annual report.

\section{Data Analyzing}

All data obtained from the survey was processed and analyzed using IBM SPSS Statistic 22. To make it easier to understand, we used " $\mathrm{R}$ " to represent "Relevance", " $\mathrm{F}$ " for "Faithful Presentation", "V" for "Verifiability", "C" for "Comparability", "U" for "Understandability", and " $T$ " for "Timeliness". We have 33 questions to access the information about the quality of annual reports.

The result in Table 2 represent each quality of annual reporting. If we look at the average of each of the qualities, we can see that they are closely rounded up around 2.00 which mean that the annual reports do not provide sufficient amount of necessary information and was not release to the public on time.

Table 3 to Table 7 describe each component of annual report quality. In Table 3, the average score of R1 is 1.23 which represents that historical cost was mostly used instead of fair value. Plus, it is noticeable that most of banks provide more than enough information about non-financial, risk, and cash flow information. Beside these, another information such as personnel policy, segment report, off-balance activities and going concern information are very limited.

Table 4 and Table 5 show the quality of faithful presentation and verifiability of annual reports. According to these tables, most of the banks provided great information of their compliance with National Bank of Cambodia (NBC), law and regulation, and accounting standard. Moreover, unqualified opinion was most received from independent auditors indicate that most of annual reports present truth and fair view of the respective financial position of the banks except in some cases that the auditors has emphasized specific issues. However, most banks provide brief information of Board of Directors' bonuses, corporate governance, negative and positive contingency, decision of estimates, and accounting principle.

The result in Table 6 shows the consistency of annual reporting. If we look at the means of all the questions, we can see that all of them receive rating below 3.00 which implies that banks do not provide sufficient information such as the changes of accounting policies, estimates, and its effect on financial position as well as other information about financial index and ratio, share and competitors of the same industry.

Last, Table 7 presents the understandability of annual report. We can see that U1 gets 3.36 point in average which indicate that banks organized their reports in well-manner and less technical jargon. In addition, the reports have moderate information about mission and strategy of the banks, as well as graph and table to clarify the information. U6 receives score 3.35 which mean that in overall the reports are understandable to researchers.

\section{Conclusion}

The purpose of this research is to evaluate the quality of annual reporting released in 2016 of the Banks in Cambodia. We used questionnaire as a tool to explore their qualitative characteristics by designed 33 questions developed by Cuong and Thi Ly (2017). Qualitative characteristics of financial reporting consist of six elements: Relevance, Faithful Presentation, Verifiability, Consistency, Understandability, and Timely. The annual reports were

\section{Volume 8 Issue 4, April 2019 www.ijsr.net}




\section{International Journal of Science and Research (IJSR) \\ ISSN: 2319-7064 \\ ResearchGate Impact Factor (2018): 0.28 | SJIF (2018): 7.426}

evaluate by 100 participants using five-point Likert type scale.

The result from our investigation shows that annual reports of the bank in Cambodia need improvement especially the consistency of the report. Among the seven qualitative characteristics of annual reporting, consistency of annual reports of bank in Cambodia receives less rating scale, 1.99. However, none of the other qualities reach 3.00 rating scale, which indicate that the annual reports need more improvement in all concepts. Most banks provided limited information which is important. In order to enhance the quality of information, it should start by presenting faithful information, adding more relevance material, and release the information on time.

This research has some limitations. First, only 33 questions which will be surveyed from participants and timing of data collection is just one year. Last, the result of the investigation will be based on personal preference and opinion of the participants.

Table 2: Summary of Annual Report Quality

\begin{tabular}{|c|c|c|c|c|c|c|}
\hline & $\mathrm{N}$ & Minimum & Maximum & Mean & Std. Deviation & Variance \\
\hline Relevance & 100 & 1.23 & 3.78 & 2.3400 & .80562 & .649 \\
\hline Faithful Presentation & 100 & 1.98 & 4.59 & 2.8980 & 1.06074 & 1.125 \\
\hline Verifiability & 100 & 2.11 & 2.91 & 2.5525 & .33049 & .109 \\
\hline Consistency & 100 & 1.24 & 2.71 & 1.9917 & .54591 & .298 \\
\hline Understandability & 100 & 1.26 & 3.36 & 2.7650 & .80037 & .641 \\
\hline Timeliness & 100 & 1.00 & 4.00 & 2.0600 & .42212 & .178 \\
\hline Quality of Annual Reports & 100 & 1.70 & 4.15 & 2.4564 & 0.56202 & .316 \\
\hline Valid N (listwise) & 100 & & & & & \\
\hline
\end{tabular}

Table 3: Relevance

\begin{tabular}{|c|c|c|c|c|c|c|}
\hline & Question & Minimum & Maximum & Mean & Std. Deviation & Variance \\
\hline Fair Value or Historical Cost & R1 & 1.00 & 5.00 & 1.2300 & .75015 & .563 \\
\hline Non-Financial Information & R2 & 2.00 & 5.00 & 3.2900 & 1.01797 & 1.036 \\
\hline Risk Information & R3 & 2.00 & 5.00 & 3.7800 & .71887 & .517 \\
\hline Forward-looking Information & R4 & 1.00 & 5.00 & 2.1900 & 1.05117 & 1.105 \\
\hline CSR Information & R5 & 1.00 & 5.00 & 1.9900 & 1.31422 & 1.727 \\
\hline Extraordinary Gains \& Losses & R6 & 1.00 & 4.00 & 1.8500 & .97830 & .957 \\
\hline Personnel Policies & R7 & 1.00 & 5.00 & 1.7500 & 1.02863 & 1.058 \\
\hline Segment Report & R8 & 1.00 & 5.00 & 1.7500 & 1.01876 & 1.038 \\
\hline Cash Flows & R9 & 2.00 & 5.00 & 3.4500 & .71598 & .513 \\
\hline Intangible Assets & R10 & 1.00 & 4.00 & 2.8500 & .97830 & .957 \\
\hline Off-balance Activities & R11 & 1.00 & 4.00 & 1.7200 & .86550 & .749 \\
\hline Financial Structure & R12 & 1.00 & 5.00 & 2.8400 & .88443 & .782 \\
\hline Going Concern Information & R13 & 1.00 & 4.00 & 1.7300 & .94125 & .886 \\
\hline Valid N (100) & & & & & & \\
\hline
\end{tabular}

Table 4: Faithful Presentation

\begin{tabular}{|c|c|c|c|c|c|c|}
\hline & Question & Minimum & Maximum & Mean & Std. Deviation & Variance \\
\hline Compliance and Application & F1 & 2.00 & 5.00 & 3.2000 & .69631 & .485 \\
\hline Board of Directors' Bonuses & F2 & 1.00 & 4.00 & 1.9800 & .76515 & .585 \\
\hline Type of Auditors' Report & F3 & 2.00 & 5.00 & 4.5900 & .71202 & .507 \\
\hline Corporate Governance & F4/V1 & 1.00 & 5.00 & 2.6100 & 1.34761 & 1.816 \\
\hline Positive \& Negative Contingencies & F5/V2 & 1.00 & 4.00 & 2.1100 & .89775 & .806 \\
\hline Valid N (1100) & & & & & & \\
\hline
\end{tabular}

Table 6: Comparability

\begin{tabular}{|c|c|c|c|c|c|c|}
\hline & Question & Minimum & Maximum & Mean & Std. Deviation & Variance \\
\hline Changes in Accounting Policies & $\mathrm{C} 1$ & 1.00 & 4.00 & 2.0000 & .89893 & .808 \\
\hline Changes in Accounting Estimates & $\mathrm{C} 2$ & 1.00 & 4.00 & 1.8800 & .90207 & .814 \\
\hline Effects of Accounting Policy Changes & $\mathrm{C} 3$ & 1.00 & 4.00 & 1.2400 & .51483 & .265 \\
\hline Financial Index Numbers \& Ratios & $\mathrm{C} 4$ & 1.00 & 5.00 & 2.7100 & 1.66542 & 2.774 \\
\hline Share Information & $\mathrm{C} 5$ & 1.00 & 5.00 & 2.5000 & .98985 & .980 \\
\hline Industry \& Competitors Information & $\mathrm{C} 6$ & 1.00 & 5.00 & 1.6200 & .95113 & .905 \\
\hline Valid N (100) & & & & & & \\
\hline
\end{tabular}

Table 7: Understandability

\begin{tabular}{|c|c|c|c|c|c|c|}
\hline & Question & Minimum & Maximum & Mean & Std. Deviation & Variance \\
\hline Well-organized Manner & U1 & 2.00 & 5.00 & 3.3600 & .82290 & .677 \\
\hline Graphs \& Tables Clarify & U2 & 1.00 & 5.00 & 2.8400 & 1.32360 & 1.752 \\
\hline Technical Jargon & U3 & 1.00 & 5.00 & 3.2100 & 1.02784 & 1.056 \\
\hline Glossary Size & U4 & 1.00 & 5.00 & 1.2600 & .81178 & .659 \\
\hline
\end{tabular}

\section{Volume 8 Issue 4, April 2019 www.ijsr.net}

Licensed Under Creative Commons Attribution CC BY 


\section{International Journal of Science and Research (IJSR) \\ ISSN: 2319-7064}

ResearchGate Impact Factor (2018): 0.28 | SJIF (2018): 7.426

\begin{tabular}{|c|c|c|c|c|c|c|}
\hline Mission \& Strategy Information & U5 & 1.00 & 5.00 & 2.5700 & .98734 & .975 \\
\hline Understandable for Researchers & U6 & 2.00 & 5.00 & 3.3500 & .83333 & .694 \\
\hline Valid N (100) & & & & & & \\
\hline
\end{tabular}

\begin{tabular}{|c|c|c|c|c|}
\hline \multicolumn{5}{|c|}{ Appendix } \\
\hline & Relevance $(\mathrm{R})$ & Operationalization & Concept & \begin{tabular}{|c|} 
Literature \\
\end{tabular} \\
\hline $\mathrm{R} 1$ & $\begin{array}{l}\text { To what extent does the } \\
\text { company use fair value } \\
\text { instead of historical cost? }\end{array}$ & $\begin{array}{c}\text { 1= Only historical cost } \\
2=\text { Mostly historical cost } \\
3=\text { Balance fair value/historical cost } \\
\text { 4= Most fair value } \\
5=\text { Only fair value }\end{array}$ & Predictive value & $\begin{array}{l}\text { (McDaniel et al., 2002); } \\
\text { (Barth et al., 2007); } \\
\text { (Beest et al., 2009); } \\
\text { (Cuong \& Thi Ly, 2017) }\end{array}$ \\
\hline $\mathrm{R} 2$ & $\begin{array}{l}\text { To what extent does the } \\
\text { presence of non-financial } \\
\text { information in terms of } \\
\text { business opportunities and } \\
\text { risks complement the } \\
\text { financial information? }\end{array}$ & $\begin{array}{c}\text { 1= No non-financial information } \\
\begin{array}{c}\text { 2= Limited non-financial information, not very useful for } \\
\text { forming expectations }\end{array} \\
\text { 3= Sufficient useful non-financial information } \\
\begin{array}{c}\text { 4= Relatively much useful non-financial information, helpful } \\
\text { for developing expectations }\end{array} \\
\text { 5= Very extensive non-financial information presents } \\
\text { additional information which helps developing expectations }\end{array}$ & Predictive value & $\begin{array}{l}\text { (Jonas \& Blanchet, } \\
\text { 2000); (Beest et al., } \\
\text { 2009); (Cuong \& Thi } \\
\text { Ly, 2017) }\end{array}$ \\
\hline R3 & $\begin{array}{l}\text { To what extent does the } \\
\text { annual report contain risk } \\
\text { information? }\end{array}$ & $\begin{array}{c}1=\text { No risk information } \\
2=\text { Limited risk information } \\
3=\text { Sufficient risk information } \\
4=\text { Relative much risk information } \\
5=\text { Very extensive risk information }\end{array}$ & Predictive value & $\begin{array}{l}\text { (Jonas \& Blanchet, } \\
\text { 2000); (Beest et al., } \\
\text { 2009); (Cuong \& Thi } \\
\text { Ly, 2017) }\end{array}$ \\
\hline $\mathrm{R} 4$ & $\begin{array}{l}\text { To what extent does the } \\
\text { annual report contain } \\
\text { forward-looking } \\
\text { information? }\end{array}$ & $\begin{array}{c}\text { 1= No forward-looking information } \\
\text { 2= Limited forward-looking information } \\
\text { 3= Sufficient forward-looking information } \\
\text { 4= Relative much forward-looking information } \\
5=\text { Very extensive forward-looking information }\end{array}$ & Predictive value & $\begin{array}{l}\text { (McDaniel et al., 2002); } \\
\text { (Jonas \& Blanchet, } \\
\text { 2000); (Beest et al., } \\
\text { 2009); (Cuong \& Thi } \\
\text { Ly, 2017) }\end{array}$ \\
\hline R5 & $\begin{array}{l}\text { To what extent does the } \\
\text { annual report contain } \\
\text { information on Corporate } \\
\text { Social Responsibility? }\end{array}$ & $\begin{array}{c}\text { 1= No information on CSR } \\
\text { 2= Limited information on CSR } \\
3=\text { Sufficient information on CSR } \\
4=\text { Very much information on CSR } \\
5=\text { Very extensive information on CSR }\end{array}$ & Predictive value & $\begin{array}{c}\text { (Craig, 2002); } \\
\text { (Beest et al., 2009); } \\
\text { (Cuong \& Thi Ly, 2017) }\end{array}$ \\
\hline R6 & $\begin{array}{l}\text { To what extent does the } \\
\text { annual report contain a } \\
\text { proper disclosure of the } \\
\text { extraordinary gains and } \\
\text { losses? }\end{array}$ & $\begin{array}{c}1=\text { No proper disclosure } \\
2=\text { Limited proper disclosure } \\
3=\text { Sufficient proper disclosure } \\
4=\text { Very much proper disclosure } \\
5=\text { Very extensive proper disclosure }\end{array}$ & \begin{tabular}{|c|} 
Predictive and \\
confirmatory value
\end{tabular} & $\begin{array}{c}\text { (Hoogendoorn \& } \\
\text { Mertens, 2001); (Beest } \\
\text { et al., 2009); (Cuong \& } \\
\text { Thi Ly, 2017) }\end{array}$ \\
\hline R7 & \begin{tabular}{|} 
To what extent the annual \\
report contains information \\
regarding personnel \\
policies?
\end{tabular} & $\begin{array}{c}\text { 1= No information regarding personnel policies } \\
\text { 2= Limited information regarding personnel policies } \\
3=\text { Sufficient information regarding personnel policies } \\
\text { 4= Very much information regarding personnel policies } \\
5=\text { Very extensive information regarding personnel policies }\end{array}$ & $\begin{array}{c}\text { Predictive and } \\
\text { confirmatory value }\end{array}$ & $\begin{array}{c}\text { (Hoogendoorn \& } \\
\text { Mertens, 2001); (Beest } \\
\text { et al., 2009); (Cuong \& } \\
\text { Thi Ly, 2017) }\end{array}$ \\
\hline R8 & $\begin{array}{l}\text { To what extent the annual } \\
\text { report contains information } \\
\text { regarding segment report? }\end{array}$ & $\begin{array}{c}\text { 1= No information segment report } \\
2=\text { Limited information segment report } \\
3=\text { Sufficient information segment report } \\
4=\text { Very much information segment report } \\
5=\text { Very extensive information segment report }\end{array}$ & \begin{tabular}{|c|} 
Predictive and \\
confirmatory value
\end{tabular} & $\begin{array}{c}\text { (Hoogendoorn \& } \\
\text { Mertens, 2001); (Beest } \\
\text { et al., 2009); (Cuong \& } \\
\text { Thi Ly, 2017) }\end{array}$ \\
\hline R9 & $\begin{array}{l}\text { To what extent does the } \\
\text { annual report contain an } \\
\text { analysis concerning cash } \\
\text { flows? }\end{array}$ & $\begin{array}{c}1=\text { No analysis } \\
2=\text { Limited analysis } \\
3=\text { Sufficient analysis } \\
4=\text { Very much analysis } \\
5=\text { Very extensive analysis }\end{array}$ & Predictive value & $\begin{array}{l}\text { (Hoogendoorn \& } \\
\text { Mertens, 2001); (Maines } \\
\& \text { Wahlen, 2006); (Beest } \\
\text { et al., 2009); (Cuong \& } \\
\text { Thi Ly, 2017) } \\
\end{array}$ \\
\hline R10 & $\begin{array}{c}\text { To what extent are the } \\
\text { intangible assets disclosed? }\end{array}$ & $\begin{array}{c}\text { 1= No disclosure } \\
\text { 2= Limited disclosure } \\
3=\text { Sufficient disclosure } \\
\text { 4= Very much disclosure } \\
5=\text { Very extensive disclosure }\end{array}$ & Predictive value & $\begin{array}{l}\text { (Camfferman \& Cooke, } \\
\text { 2002); (Beest et al., } \\
\text { 2009); (Cuong \& Thi } \\
\text { Ly, 2017) }\end{array}$ \\
\hline R11 & $\begin{array}{c}\text { To what extent are the "off- } \\
\text { balance" activities } \\
\text { disclosed? }\end{array}$ & $\begin{array}{c}\text { 1= No disclosure } \\
\text { 2= Limited disclosure } \\
3=\text { Sufficient disclosure } \\
\text { 4= Very much disclosure } \\
5=\text { Very extensive disclosure }\end{array}$ & Predictive value & $\begin{array}{c}\text { (Hoogendoorn \& } \\
\text { Mertens, 2001); (Beest } \\
\text { et al., 2009); (Cuong \& } \\
\text { Thi Ly, 2017) }\end{array}$ \\
\hline R12 & $\begin{array}{l}\text { To what extent is the } \\
\text { financial structure } \\
\text { disclosed? }\end{array}$ & $\begin{array}{c}\text { 1= No disclosure } \\
\text { 2= Limited disclosure } \\
3=\text { Sufficient disclosure } \\
\text { 4= Very much disclosure }\end{array}$ & Predictive value & $\begin{array}{l}\text { (Vander Bauwhede, } \\
\text { 2001); (Beest et al., } \\
\text { 2009); (Cuong \& Thi } \\
\text { Ly, 2017) }\end{array}$ \\
\hline
\end{tabular}

Volume 8 Issue 4, April 2019 www.ijsr.net

Licensed Under Creative Commons Attribution CC BY 


\section{International Journal of Science and Research (IJSR) \\ ISSN: 2319-7064}

ResearchGate Impact Factor (2018): 0.28 | SJIF (2018): 7.426

\begin{tabular}{|c|c|c|c|c|}
\hline & & $5=$ Very extensive disclosure & & \\
\hline R13 & $\begin{array}{l}\text { To what extent does the } \\
\text { annual report contain } \\
\text { information concerning the } \\
\text { companies' going concern? }\end{array}$ & $\begin{array}{c}1 \text { = No information concerning going concern } \\
2=\text { Limited information concerning going concern } \\
3=\text { Sufficient information concerning going concern } \\
4=\text { Very much information concerning going concern } \\
5=\text { Very extensive information concerning going concern }\end{array}$ & Predictive value & $\begin{array}{c}\text { (Dear, 2008); (Beest et } \\
\text { al., 2009); (Cuong \& Thi } \\
\text { Ly, 2017) }\end{array}$ \\
\hline \multicolumn{2}{|r|}{ Faithful Presentation $(\mathrm{F})$} & Operationalization & Concept & Literature \\
\hline F1 & $\begin{array}{l}\text { To what extent does the } \\
\text { annual report contain } \\
\text { disclosure concerning the } \\
\text { compliance and explain } \\
\text { application? }\end{array}$ & $\begin{array}{c}\text { 1= No disclosure } \\
2=\text { Limited disclosure } \\
3=\text { Sufficient disclosure } \\
4=\text { Very much disclosure } \\
5=\text { Very extensive disclosure }\end{array}$ & Neutrality & $\begin{array}{l}\text { (Jonas \& Blanchet, } \\
\text { 2000); (Beest et al., } \\
\text { 2009); (Cuong \& Thi } \\
\text { Ly, 2017) }\end{array}$ \\
\hline F2 & $\begin{array}{l}\text { To what extent does the } \\
\text { annual report contain } \\
\text { information concerning } \\
\text { bonuses of the board of } \\
\text { directors? }\end{array}$ & $\begin{array}{c}\text { 1= No information concerning bonuses } \\
\text { 2= Limited information concerning bonuses } \\
3=\text { Sufficient information concerning bonuses } \\
\text { 4= Very much information concerning bonuses } \\
5=\text { Very extensive information concerning bonuses }\end{array}$ & Neutrality & $\begin{array}{c}\text { (Burgstahler, Hail, \& } \\
\text { Leuz, 2006); (Beest et } \\
\text { al., 2009); (Cuong \& Thi } \\
\text { Ly, 2017) }\end{array}$ \\
\hline F3 & $\begin{array}{l}\text { Which type of auditors' } \\
\text { report is included in the } \\
\text { annual report? }\end{array}$ & $\begin{array}{c}1=\text { Adverse opinion } \\
2=\text { Disclaimer of opinion } \\
3=\text { Qualified opinion } \\
\text { 4=Unqualified opinion: financial figures/emphasis/other } \\
\text { issues } \\
5=\text { Unqualified opinion: financial figures }\end{array}$ & $\begin{array}{c}\text { Free from material } \\
\text { error, verification, } \\
\text { neutrality, and } \\
\text { completeness }\end{array}$ & $\begin{array}{l}\text { (Maines \& Wahlen, } \\
\text { 2006); (Gray, Turner, } \\
\text { Coram, \& Mock, 2011); } \\
\text { (Beest et al., 2009); } \\
\text { (Cuong \& Thi Ly, 2017) }\end{array}$ \\
\hline $\begin{array}{l}\text { F4 } \\
\text { V1 }\end{array}$ & $\begin{array}{l}\text { To what extent does the } \\
\text { company provide } \\
\text { information on corporate } \\
\text { governance? }\end{array}$ & $\begin{array}{c}\text { 1= No description of corporate governance } \\
\text { 2= Limited description of corporate governance } \\
3=\text { Sufficient description of corporate governance } \\
4=\text { Very much description of corporate governance } \\
5=\text { Very extensive description of corporate governance }\end{array}$ & $\begin{array}{c}\text { Completeness, } \\
\text { Verifiability, and } \\
\text { free from material } \\
\text { error }\end{array}$ & $\begin{array}{l}\text { (Jonas \& Blanchet, } \\
\text { 2000); (Beest et al., } \\
\text { 2009); (Cuong \& Thi } \\
\text { Ly, 2017) }\end{array}$ \\
\hline $\begin{array}{l}\text { F5 } \\
\text { V2 }\end{array}$ & $\begin{array}{l}\text { To what extent does the } \\
\text { annual report contain } \\
\text { disclosure related to both } \\
\text { positive and negative } \\
\text { contingencies? }\end{array}$ & $\begin{array}{c}1=\text { No disclosure } \\
2=\text { Limited disclosure } \\
3=\text { Sufficient disclosure } \\
4=\text { Very much disclosure } \\
5=\text { Very extensive disclosure }\end{array}$ & $\begin{array}{c}\text { Completeness and } \\
\text { verifiability }\end{array}$ & $\begin{array}{c}\text { (Cohen et al., 2004); } \\
\text { (Beest et al., 2009); } \\
\text { (Cuong \& Thi Ly, 2017) }\end{array}$ \\
\hline \multicolumn{2}{|r|}{ Verifiability (V) } & Operationalization & Concept & Literature \\
\hline V3 & $\begin{array}{l}\text { To what extent are valid } \\
\text { arguments provide to } \\
\text { support the decision for } \\
\text { estimates in the annual } \\
\text { report? }\end{array}$ & $\begin{array}{c}\text { 1= No valid arguments } \\
\text { 2= Limited valid arguments } \\
\text { 3= Sufficient valid arguments } \\
\text { 4= Very much valid arguments } \\
\text { 5= Very extensive valid arguments }\end{array}$ & Verifiability & $\begin{array}{l}\text { (Maines \& Wahlen, } \\
\text { 2006); (Beest et al., } \\
\text { 2009); (Cuong \& Thi } \\
\text { Ly, 2017) }\end{array}$ \\
\hline V4 & $\begin{array}{l}\text { To what extent does the } \\
\text { company compliance with } \\
\text { accounting principles on } \\
\text { valid arguments? }\end{array}$ & $\begin{array}{c}\text { 1= No valid arguments } \\
\text { 2= Limited valid arguments } \\
\text { 3= Sufficient valid arguments } \\
\text { 4= Very much valid arguments } \\
\text { 5= Very extensive valid arguments }\end{array}$ & Verification & \begin{tabular}{|l} 
(Jonas \& Blanchet, \\
2000); (Maines \& \\
Wahlen, 2006); (Beest et \\
al., 2009); (Cuong \& Thi \\
Ly, 2017)
\end{tabular} \\
\hline \multicolumn{2}{|r|}{ Comparability $(\mathrm{C})$} & Operationalization & Concept & Literature \\
\hline $\mathrm{C} 1$ & $\begin{array}{c}\text { To what extent are changes } \\
\text { in accounting policies } \\
\text { disclosed? }\end{array}$ & $\begin{array}{c}\text { 1= No disclosure } \\
2=\text { Limited disclosure } \\
3=\text { Sufficient disclosure } \\
4=\text { Very much disclosure } \\
5=\text { Very extensive disclosure }\end{array}$ & Consistency & $\begin{array}{l}\text { (Jonas \& Blanchet, } \\
\text { 2000); (Beest et al., } \\
\text { 2009); (Cuong \& Thi } \\
\text { Ly, 2017) }\end{array}$ \\
\hline $\mathrm{C} 2$ & $\begin{array}{c}\text { To what extent are changes } \\
\text { in accounting estimates } \\
\text { disclosed? }\end{array}$ & $\begin{array}{c}\text { 1= No disclosure } \\
\text { 2= Limited disclosure } \\
3=\text { Sufficient disclosure } \\
\text { 4= Very much disclosure } \\
\text { 5= Very extensive disclosure }\end{array}$ & Consistency & $\begin{array}{l}\text { (Jonas \& Blanchet, } \\
\text { 2000); (Beest et al., } \\
\text { 2009); (Cuong \& Thi } \\
\text { Ly, 2017) }\end{array}$ \\
\hline $\mathrm{C} 3$ & $\begin{array}{l}\text { To what extent does the } \\
\text { annual report contain } \\
\text { information concerning } \\
\text { comparison and effects of } \\
\text { accounting policy changes? }\end{array}$ & $\begin{array}{c}\text { 1= No comparison } \\
2=\text { Actual adjustments }(1 \text { year }) \\
\quad 3=2 \text { years } \\
4=3 \text { years } \\
5=4 \text { or more years }\end{array}$ & Consistency & $\begin{array}{l}\text { (Jonas \& Blanchet, } \\
\text { 2000); (Beest et al., } \\
\text { 2009); (Cuong \& Thi } \\
\text { Ly, 2017) }\end{array}$ \\
\hline C4 & $\begin{array}{c}\text { To what extent does the } \\
\text { company present financial } \\
\text { index numbers and ratios in } \\
\text { the annual report? }\end{array}$ & $\begin{array}{c}1=\text { No ratios } \\
2=1-5 \text { ratios } \\
3=6-10 \text { ratios } \\
4=11-15 \text { ratios } \\
5=>15 \text { ratios }\end{array}$ & Comparability & $\begin{array}{c}\text { (Cleary, 1999); (Beest et } \\
\text { al., 2009); (Cuong \& Thi } \\
\text { Ly, 2017) }\end{array}$ \\
\hline $\mathrm{C} 5$ & $\begin{array}{l}\text { To what extent does the } \\
\text { annual report contain } \\
\text { information concerning }\end{array}$ & $\begin{array}{c}\text { 1= No information concerning companies' shares } \\
2=\text { Limited information concerning } \\
\text { companies' shares }\end{array}$ & Consistency & $\begin{array}{l}\text { (Jonas \& Blanchet, } \\
\text { 2000); (Beest et al., } \\
\text { 2009); (Cuong \& Thi }\end{array}$ \\
\hline
\end{tabular}

Volume 8 Issue 4, April 2019 www.ijsr.net

Licensed Under Creative Commons Attribution CC BY 
International Journal of Science and Research (IJSR)

ISSN: 2319-7064

ResearchGate Impact Factor (2018): 0.28 | SJIF (2018): 7.426

\begin{tabular}{|c|c|c|c|c|}
\hline & companies' shares? & $\begin{array}{c}\text { 3= Sufficient information concerning } \\
\text { companies's shares } \\
4=\text { Very much information concerning } \\
\text { companies' shares } \\
5=\text { Very extensive information concerning companies' shares }\end{array}$ & & Ly, 2017) \\
\hline C6 & $\begin{array}{l}\text { To what extent does the } \\
\text { annual report contain } \\
\text { information concerning } \\
\text { industry and competitors? }\end{array}$ & $\begin{array}{c}1=\text { No disclosure } \\
2=\text { Limited disclosure } \\
3=\text { Sufficient disclosure } \\
4=\text { Very much disclosure } \\
5=\text { Very extensive disclosure } \\
\end{array}$ & Consistency & $\begin{array}{l}\text { (Armstrong, Barth, } \\
\text { Jagolinzer, \& Riedl, } \\
\text { 2010); (Beest et al., } \\
\text { 2009); (Cuong \& Thi } \\
\text { Ly, 2017) }\end{array}$ \\
\hline & Understandability (U) & Operationalization & Concept & Literature \\
\hline $\mathrm{U} 1$ & $\begin{array}{c}\text { To what extent is the annual } \\
\text { report presented in a well- } \\
\text { organized manner? }\end{array}$ & $\begin{array}{c}1=\text { Very bad presentation } \\
2=\text { Bad presentation } \\
3=\text { Poor presentation } \\
4=\text { Good presentation } \\
5=\text { Very good presentation }\end{array}$ & Understandability & $\begin{array}{l}\text { (Jonas \& Blanchet, } \\
\text { 2000); (Beest et al., } \\
\text { 2009); (Cuong \& Thi } \\
\text { Ly, 2017) }\end{array}$ \\
\hline $\mathrm{U} 2$ & $\begin{array}{l}\text { To what extent does the } \\
\text { presence of graphs and } \\
\text { tables clarify the presented } \\
\text { information? }\end{array}$ & $\begin{array}{c}1=\text { No graphs } \\
2=1-5 \text { graphs } \\
3=6-10 \text { graphs } \\
4=11-15 \text { graphs } \\
5=>15 \text { graphs }\end{array}$ & Understandability & $\begin{array}{c}\text { (Jonas \& Blanchet, } \\
\text { 2000); (Lennard, 2007); } \\
\text { (Beest et al., 2009); } \\
\text { (Cuong \& Thi Ly, 2017) }\end{array}$ \\
\hline $\mathrm{U} 3$ & $\begin{array}{l}\text { To what extent does the } \\
\text { annual report contain } \\
\text { technical jargon in the } \\
\text { perception of the } \\
\text { researcher? }\end{array}$ & $\begin{array}{l}\text { 1= Very much jargon } \\
\text { 2= Much jargon } \\
\text { 3= Moderate use of jargon } \\
\text { 4= Limited use of jargon } \\
5=\text { No/hardly any jargon }\end{array}$ & Understandability & $\begin{array}{c}\text { (Jonas \& Blanchet, } \\
\text { 2000); (Lennard, 2007); } \\
\text { (Beest et al., 2009); } \\
\text { (Cuong \& Thi Ly, 2017) }\end{array}$ \\
\hline $\mathrm{U} 4$ & $\begin{array}{l}\text { What is the size of the } \\
\text { glossary? }\end{array}$ & $\begin{array}{c}1=\text { No glossary } \\
2=\text { Less than } 1 \text { page } \\
3=\text { Approximately } 1 \text { page } \\
4=1-2 \text { pages } \\
5=>2 \text { pages }\end{array}$ & Understandability & $\begin{array}{l}\text { (Jonas \& Blanchet, } \\
\text { 2000); (Beest et al., } \\
\text { 2009); (Cuong \& Thi } \\
\text { Ly, 2017) }\end{array}$ \\
\hline U5 & $\begin{array}{l}\text { To what extent does the } \\
\text { annual report contain } \\
\text { information concerning } \\
\text { mission and strategy? }\end{array}$ & $\begin{array}{c}\text { 1= No information concerning mission and strategy } \\
2=\text { Limited information concerning mission and strategy } \\
3=\text { Sufficient information concerning mission and strategy } \\
\text { 4= Very much information concerning mission and strategy } \\
\text { 5= Very extensive information }\end{array}$ & Understandability & $\begin{array}{l}\text { (Board, 2010); (Men \& } \\
\text { Wang, 2008); (Beest et } \\
\text { al., 2009); (Cuong \& Thi } \\
\text { Ly, 2017) }\end{array}$ \\
\hline U6 & $\begin{array}{c}\text { To what extent is the annual } \\
\text { report understandable in the } \\
\text { perception of the } \\
\text { researcher? }\end{array}$ & $\begin{array}{c}\text { 1= Very badly understandable } \\
2=\text { Badly understandable } \\
3=\text { Poor understandable } \\
4=\text { Good understandable } \\
5=\text { Very good understandable }\end{array}$ & Understandability & $\begin{array}{c}\text { (Courtis, 1995); (Beest } \\
\text { et al., 2009); (Cuong \& } \\
\text { Thi Ly, 2017) }\end{array}$ \\
\hline & Timeliness $(\mathrm{T})$ & Operationalization & Concept & Literature \\
\hline $\mathrm{T} 1$ & $\begin{array}{l}\text { How many days did it take } \\
\text { for the auditor to sign the } \\
\text { auditors' report after the } \\
\text { book-year end? }\end{array}$ & $\begin{array}{l}\qquad \begin{aligned} 1 & =5-5.99 \\
2 & =4-4.99 \\
3 & =3-3.99 \\
4 & =2-2.99 \\
5 & =1-1.99\end{aligned} \\
\text { Natural logarithm of amount of days } \operatorname{Ln}(\mathrm{T} 1)=(\text { Release Date } \\
\text { audit report -Financial year end date) }\end{array}$ & Timeliness & $\begin{array}{l}\text { (Dear, 2008); (Leventis } \\
\text { \& Weetman, 2004); } \\
\text { (Beest et al., 2009); } \\
\text { (Cuong \& Thi Ly, 2017) }\end{array}$ \\
\hline
\end{tabular}

\section{References}

[1] Armstrong, Christopher S, Barth, Mary E, Jagolinzer, Alan D, \& Riedl, Edward J. (2010). Market reaction to the adoption of IFRS in Europe. The accounting review, 85(1), 31-61.

[2] Bailey, Andrew D., \& Gramling, Audrey A. FINANCIAL REPORTING QUALITY Research on Professional Responsibility and Ethics in Accounting (pp. 3-34).

[3] Barth, Mary E., Landsman, Wayne R., Lang, Mark H., Stanford, University, \& Graduate School of, Business. (2007). International accounting standards and accounting quality. Stanford, CA: Graduate School of Business, Stanford University.
[4] Beest, Ferdy Van, Braam, Geert, \& Boelens, Suzanne. (2009). Quality of Financial Reporting: measuring qualitative characteristics. (09-108), 2, 9, 20,21.

[5] Board, Financial Accounting Standards. (2010). Conceptual Framework for Financial Reporting: Chapter 1, The Objective of General Purpose Financial Reporting, and Chapter 3, Qualitative Characteristics of Useful Financial Information. Statement of Financial Accounting Concept No. 8: FASB Norwalk, CT.

[6] Burgstahler, David C, Hail, Luzi, \& Leuz, Christian. (2006). The importance of reporting incentives: Earnings management in European private and public firms. The accounting review, 81(5), 983-1016.

[7] Camfferman, Kees, \& Cooke, Terence E. (2002). An analysis of disclosure in the annual reports of UK and

\section{Volume 8 Issue 4, April 2019 www.ijsr.net}




\section{International Journal of Science and Research (IJSR) \\ ISSN: 2319-7064}

ResearchGate Impact Factor (2018): 0.28 | SJIF (2018): 7.426

Dutch companies. Journal of International Accounting Research, 1(1), 3-30.

[8] Cleary, Sean. (1999). The relationship between firm investment and financial status. The Journal of Finance, 54(2), 673-692.

[9] Cohen, Jeffrey R, Krishnamoorthy, Ganesh, \& Wright, Arnold. (2004). The corporate governance mosaic and financial reporting quality.

[10] Courtis, John K. (1995). Readability of annual reports: Western versus Asian evidence. Accounting, Auditing \& Accountability Journal, 8(2), 4-17.

[11]Craig, Deegan. (2002). Introduction: The legitimising effect of social and environmental disclosures - a theoretical foundation. Accounting, Auditing \& Accountability Journal, 15(3), 282-311. doi: doi:10.1108/09513570210435852

[12]Cuong, Nguyen Thanh, \& Thi Ly, Do. (2017). Measuring and Assessing the Quality of Information on the Annual Reports: The Case of Seafood's Companies Listed on the Vietnam Stock Market (Vol. 160).

[13]Dear, IASB. (2008). Exposure Draft-Conceptual Framework for Financial Reporting.

[14]Eun, Cheol S., \& Resnick, Bruce G. (2012). International Financial Management (6th ed.): McGraw-Hill Companies Inc.

[15]Finance, The Ministry of Economy and. (2017). Cambodian Accounting Standards (CAS).

[16]Forker, John J. (1992). Corporate governance and disclosure quality. Accounting and Business research, 22(86), 111-124.

[17] Gray, Glen L, Turner, Jerry L, Coram, Paul J, \& Mock, Theodore J. (2011). Perceptions and misperceptions regarding the unqualified auditor's report by financial statement preparers, users, and auditors. Accounting Horizons, 25(4), 659-684.

[18] Hasan, Md, Abdullah, Shamsul Nahar, \& Hossain, Syed Zabid Hossain. (2014). Qualitative characteristics of financial reporting. The Pakistan Accountant, 50(1), 2331.

[19] Hoogendoorn, Martinus Nico, \& Mertens, Gerardus Maria Hubertus. (2001). Kwaliteit van externe financiële verslaggeving in Nederland.

[20] Hunton, James E, Libby, Robert, \& Mazza, Cheri L. (2006). Financial Reporting Transparency and Earnings Management (Retracted). The Accounting Review, 81(1), 135-157.

[21] International Financial Reporting Standard. (2010) Conceptual Framework for Financial Reporting.

[22] Jonas, Gregory J., \& Blanchet, Jeannot. (2000). Assessing Quality of Financial Reporting. Accounting Horizons, 14(3), 353-363. doi: 10.2308/acch.2000.14.3.353

[23]Lennard, Andrew. (2007). Stewardship and the objectives of financial statements: a comment on IASB's preliminary views on an improved conceptual framework for financial reporting: the objective of financial reporting and qualitative characteristics of decision-useful financial reporting information. Accounting in Europe, 4(1), 51-66.

[24]Leventis, Stergios, \& Weetman, Pauline. (2004). Timeliness of financial reporting: applicability of disclosure theories in an emerging capital market. Accounting and Business Research, 34(1), 43-56.

[25] Maines, Laureen A, \& Wahlen, James M. (2006). The nature of accounting information reliability: Inferences from archival and experimental research. Accounting Horizons, 20(4), 399-425.

[26] McDaniel, Linda, Martin, Roger D, \& Maines, Laureen A. (2002). Evaluating financial reporting quality: The effects of financial expertise vs. financial literacy. The accounting review, 77(s-1), 139-167.

[27] Men, Rong, \& Wang, Hui. (2008). Analysis on the quality of strategic information disclosure in listed steel companies-Based on annual report. Paper presented at the Orient Academic Forum.

[28] Nicolaisen, D. (2004). Remarks before the 2004 AICPA national conference on current SEC and PCAOB developments. Extraído desde http://www. sec. gov/news/speech/spchl20604dtn. htm[Links].

[29]Pivac, Snjezana, Vuko, Tina, \& Cular, Marko. (2017). Analysis of annual report disclosure quality for listed companies in transition countries. Economic ResearchEkonomska Istraživanja, 30(1), 721-731. doi: 10.1080/1331677X.2017.1311231

[30] Qingliang, Tang, Huifa, Chen, \& Zhijun, Lin. (2016). How to measure country-level financial reporting quality? Journal of Financial Reporting and Accounting, 14(2), 230-265. doi: doi:10.1108/JFRA-092014-0073

[31] Schipper, Katherine, \& Vincent, Linda. (2003). Earnings quality. Accounting horizons, 17, 97-110.

[32] Vander Bauwhede, Heidi. (2001). What factors influence financial statement quality? A framework and some empirical evidence: Working Paper. Retrieved from http://venus. unive. it/bauhaus/Heidi\% 20Vander\% 20Bauwhede. PDF.

[33] Whittington, Geoffrey. (2008). Harmonisation or discord? The critical role of the IASB conceptual framework review. Journal of Accounting and Public Policy, 27(6), 495-502.

[34] The World Bank in Cambodia. (2017, Oct, 2017). Retrieved Dec 27, 2017, 2017, from http://www.worldbank.org/en/country/cambodia/overvie $\mathrm{w}$

\section{Volume 8 Issue 4, April 2019 www.ijsr.net}

